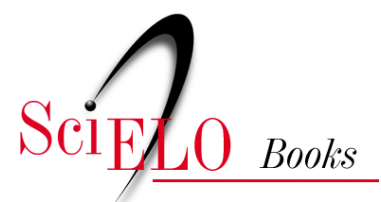

\title{
47. Evaristo de Paula, um Nome Esquecido na História da Descoberta da Doença de Chagas
}

\author{
Joffre Marcondes de Rezende
}

\section{SciELO Books / SciELO Livros / SciELO Libros}

REZENDE, J. M. Evaristo de Paula, um Nome Esquecido na História da Descoberta da Doença de Chagas. In: À sombra do plátano: crônicas de história da medicina [online]. São Paulo: Editora Unifesp, 2009, pp. 381-383. História da Medicina series, vol. 2. ISBN 97885-61673-63-5. https://doi.org/10.7476/9788561673635.0048.

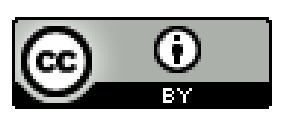

All the contents of this work, except where otherwise noted, is licensed under a Creative Commons Attribution 4.0 International license.

Todo o conteúdo deste trabalho, exceto quando houver ressalva, é publicado sob a licença Creative Commons Atribição 4.0.

Todo el contenido de esta obra, excepto donde se indique lo contrario, está bajo licencia de la licencia Creative Commons Reconocimento 4.0. 


\section{Evaristo de Paula, um Nome Esquecido na História da Descoberta da Doença de Chagas*}

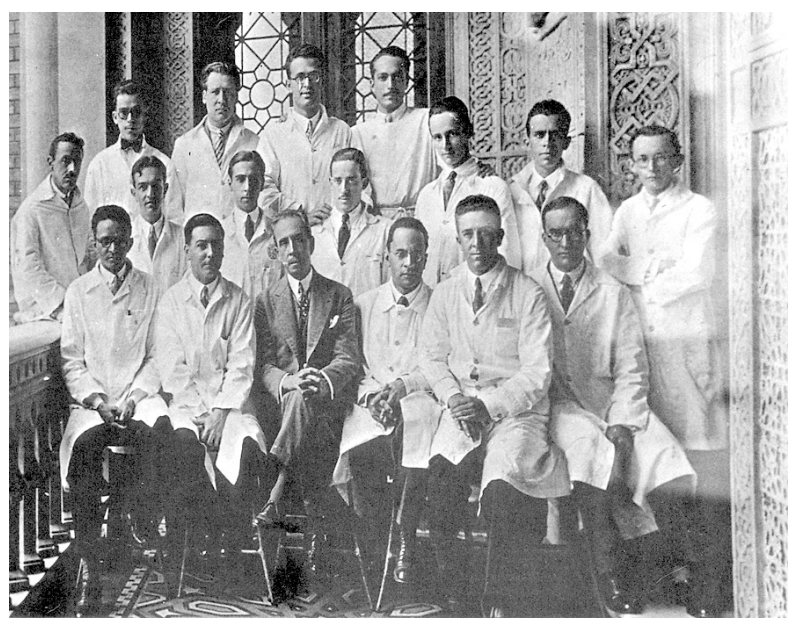

Carlos Chagas e sua equipe do Instituto Oswaldo Cruz no Rio de Janeiro.

É fato conhecido e narrado em todas as publicações que abordam a descoberta da doença de Chagas, que Carlos Chagas teve sua atenção despertada para o barbeiro pelo engenheiro Cornélio Homem Cantarino Motta $^{\mathrm{I}}$, quando ambos pernoitaram no acampamento à margem do riacho Buriti Pequeno.

Cantarino Motta era o chefe da comissão de engenheiros encarregada da construção do trecho da Estrada de Ferro Central do Brasil que levava os trilhos até a cidade de Pirapora e havia solicitado a presença ali de um médico especialista em malária, que acometia os trabalhadores, impedindo a continuação das obras. Carlos Chagas e Belisário Penna foram os médicos indicados por Oswaldo Cruz para atender a solicitação de Cantarino

* Carta ao Editor, publicada na Revista de Patologia Tropical, 37 (2), pp. I83-ı84, 2008.

I. Os dados referentes a Cantarino Motta foram obtidos graças à prestimosa colaboração da dra. Simone Petraglia Kropf, a quem muito agradecemos. 
Motta e trasladaram-se para Lassance, uma pequena estação ferroviária nas proximidades das obras.

Ao apresentar um exemplar do inseto, Cantarino Motta mencionara a existência dos triatomíneos nas cafuas de pau a pique e seu hematofagismo, sugerindo a possibilidade do barbeiro causar doença no homem, a semelhança do mosquito da malária. Foi a centelha que despertou o gênio de Carlos Chagas para as investigações que se seguiram. O próprio Chagas assim narra o episódio em um retrospecto histórico de sua descoberta.

Mais de um ano permanecemos naquela zona, sem que houvéssemos sabido da existência ali, nas choupanas dos regionais, de um inseto hematófago, denominado vulgarmente barbeiro, chupão ou chupança [...] Numa viagem a Pirapora, e quando pernoitávamos, Belisário Penna e eu, no acampamento de engenheiros, encarregados dos estudos da linha férrea, conhecemos o barbeiro, que nos foi mostrado por Cantarino Motta, chefe da comissão de engenheiros. - E, mais adiante - [...] ficamos logo interessados em conhecer o barbeiro na sua biologia exata, e principalmente em verificar a hipótese de ser ele, acaso, o transmissor de algum parasito ao homem, ou a outro vertebrado (Chagas, I922).

O nome de Cantarino Motta ficou definitivamente associado à história da descoberta da doença de Chagas. O que habitualmente deixa de ser referido é como Cantarino Motta, que se encontrava há relativamente pouco tempo na região, tomou conhecimento do barbeiro e do hábito deste inseto de sugar o sangue das pessoas à noite, enquanto dormem.

Em entrevista concedida à revista Singra, em 1954 ele próprio nos revela este pormenor histórico. Reproduzimos, a seguir, o trecho da entrevista referente ao fato:

O seu a seu dono. Não havia eu criado aquela relação entre o barbeiro e os papudos. O coronel Evaristo de Paula dizia que não era só o mosquito que chupava o sangue da gente, mas que o barbeiro também o fazia. Por isso conviria evitar suas picadas, pois quem sabe se ele também não causa mal. O que transmiti, pois, a Carlos Chagas, era quase uma convicção resultante das observações feitas depois que o coronel Evaristo de Paula me chamara a atenção para o inseto hematófago (Motta, I954). 
Já sabíamos deste fato por informação do prof. Edmundo de Paula Pinto, parente de Evaristo de Paula e ilustre professor da Faculdade de Medicina da Universidade de Minas Gerais. Em carta que dele recebemos, datada de I 5 de janeiro de 1964, ele não só relatava o fato como nos esclarecia que "o convívio e amizade entre Cantarino Motta e Evaristo de Paula se deu em Curvelo, local 'civilizado' mais próximo de Lassance e para onde se dirigiam os engenheiros nos fins de semana".

Cantarino Motta faleceu em I959, aos noventa anos, na cidade do Rio de Janeiro, no mesmo ano em que se comemorava o cinquentenário da grande descoberta de Carlos Chagas e se realizava naquela cidade o i Congresso Internacional sobre a Doença de Chagas.

Não dispomos de dados biográficos de Evaristo de Paula. O prof. Edmundo de Paula Pinto a ele se refere como "um mineiro simples do interior". Em I954, o deputado Vasconcelos Costa apresentou à Câmara Federal a proposição de denominar "Capitão Evaristo" à estação de Tamboril da Estrada de Ferro Central do Brasil em Curvelo, "em reconhecimento à sua participação nos fatos que levaram o eminente médico brasileiro (Carlos Chagas) à feliz descoberta”. A proposição foi aprovada pela lei no $2.673 / 55$ (Câmara dos Deputados, I955).

$\mathrm{Na}$ literatura médica consultada, encontramos referência a Evaristo de Paula unicamente no livro de Milton Carneiro, professor de parasitologia da Universidade Federal do Paraná (Carneiro, I963, p. 5).

\section{Referências Bibliográficas}

Câmara dos Deputados. Diário Oficial, I6 dez. I955.

Carneiro, M. História da Doença de Chagas. Curitiba, (s. n.) I963.

Chagas, C. "Descoberta do Tripanozoma cruzi e Verificação da Tripanozomiase Americana. Retrospecto histórico”. Memórias do Instituto Oswaldo Cruz, I 5 (I), pp. 67-76, I922.

MotтA, C. "Entrevista”. Singra, vol. viı, n. Io, I954. 
